Zeszyty Naukowe Szkoły Głównej Gospodarstwa Wiejskiego w Warszawie

Problemy Rolnictwa Światowego tom 18 (XXXIII), zeszyt 3, 2018: 342-352

DOI: $10.22630 /$ PRS.2018.18.3.92

Jadwiga Zaród ${ }^{1}$

Zachodniopomorski Uniwersytet Technologiczny w Szczecinie

\title{
Identyfikacja głównych determinant rozwoju rolnictwa w krajach Unii Europejskie
}

\section{Identification of the Main Determinants of Agricultural Development in the European Union Countries}

\begin{abstract}
Synopsis. Poziom rozwoju rolnictwa w krajach UE jest zróżnicowany. Znajomość czynników bezpośrednio oddziałujących na przemiany w rolnictwie może przyczynić się do zmniejszania dysproporcji pomiędzy państwami. Celem tego opracowania jest wskazanie głównych czynników determinujących rozwój rolnictwa w Unii. Do realizacji tego zadania wykorzystano analizę dyskryminacyjną. Natomiast materiał badawczy stanowiły dane GUS i EUROSTATU, dotyczące rolnictwa w krajach UE. Z przeprowadzonych badań wynika, że rozwój rolnictwa w UE determinuja szczególnie takie czynniki jak: produktywności pracy, udział zasiewu zbóż w ogólnej powierzchni gruntów ornych, dochód rolniczy oraz wydatki na spożycie w gospodarstwach domowych. Ponadto analiza dyskryminacyjna pozwoliła przypisać poszczególne kraje do grup o różnym poziomie rozwoju rolnictwa.
\end{abstract}

Slowa kluczowe: analiza dyskryminacyjna, determinanty rozwoju rolnictwa, klasyfikacja krajów UE

\begin{abstract}
The level of agricultural development in the EU countries is varies significantly. The knowledge of factors directly affecting changes in agriculture can contribute to reducing disparities between countries. The purpose of this study is to indicate the main factors which determine agricultural development in the European Union. To implement this task, the discriminant analysis was used. The research material were data from the GUS and EUROSTAT regarding agriculture in EU countries. The research shows that the development of agriculture in the EU is determined in particular by factors such as the share of sowing of cereals in the total area of arable land, consumption expenditure in households, labor productivity and agricultural income. In addition, the discriminatory analysis allowed assigning particular countries to groups with different levels of agricultural development.
\end{abstract}

Keywords: discriminatory analysis, determinants of agricultural development, classification of EU countries

JEL Classification: C38, O13, Q12

\section{Wprowadzenie}

Poziom rozwoju rolnictwa w krajach UE jest zróżnicowany. Różnice te wynikają z uwarunkowań przyrodniczych, historycznych i politycznych Współcześnie kierunki ewolucji struktur rolnych, w poszczególnych krajach unijnych, kształtują aspekty społeczne (zapewniające bezpieczeństwo żywnościowe), ekonomiczne (gwarantujące opłacalność produkcji) oraz środowiskowe (związane z utrzymaniem odpowiedniej jakości rolniczej przestrzeni produkcyjnej) (Reardon, Barrett, 2000; Sadowski i in., 2015).

${ }^{1}$ dr inż., Katedra Zastosowań Matematyki w Ekonomii ZUT, ul. Janickiego 31, 71-270 Szczecin, e-mail: jzarod@zut.edu.pl; https://orcid.org/0000-0002-3771-0490 
Przygodzka (2006) determinanty rozwoju rolnictwa dzieli na: wewnętrzne (endoagrarne) i zewnętrzne (egzoagrarne). Endoagrarne czynniki to przede wszystkim zasoby: ziemi, pracy i kapitału oraz struktura agrarna. Czynniki egzoagrarne to głównie popyt na artykuły żywnościowe i surowce pochodzenia rolniczego (w tym eksport) oraz podaż środków do produkcji rolniczej i ich dostępność cenowa. Tomczak (2006) czynniki wewnętrzne opisuje za pomocą zmiennych: wydajność pracy w rolnictwie w przeliczeniu na 1 zatrudnionego, zatrudnienie $\mathrm{w}$ rolnictwie w \% ogółu zatrudnionych, wielkość gospodarstw (rozmiar, struktura), skala produkcji, poziom dochodu rolniczego w przeliczeniu na 1 zatrudnionego $\mathrm{w}$ rolnictwie, wyposażenie i równowaga czynników produkcji, udział sprzedaży $\mathrm{w}$ produkcji (produkcja towarowa), udział konsumpcji naturalnej w produkcji rolnej. Natomiast wśród najważniejszych uwarunkowań zewnętrznych wymienia: poziom rozwoju gospodarczego kraju, udział rolnictwa w PKB, możliwości zatrudnienia poza rolnictwem, wydatki na żywność w \% PKB oraz poziom handlu zagranicznego w przeliczeniu na 1 zatrudnionego.

Czynniki te wykorzystano w tym opracowaniu do podziału krajów UE na grupy różniące się pod względem rozwoju rolnictwa. Badaniem poziomu rozwoju rolnictwa krajów unijnych zajmowały się też Bear-Nawrocka i Markiewicz (2010). Na podstawie wybranych zmiennych (powierzchnia gospodarstwa, zatrudnienie, aktywa ogółem, techniczne uzbrojenie pracy, nakłady środków obrotowych i trwałych) wyodrębniły cztery grupy typologiczne metodą mierników syntetycznych. Również poziom rozwoju rolnictwa za pomoca mierników syntetycznych badały Janiszewska i Ossowska (2014). Autorki podzieliły państwa Unii na trzy grupy, skupiające kraje o podobnych cechach takich jak: średnia powierzchnia użytków rolnych, obsada zwierząt, produktywność ziemi oraz plony zbóż. Natomiast Szczukocka (2015) badała rozwój sektora rolnego w Polsce i krajach Unii metodą skalowania wielowymiarowego. Na podstawowe czynników dotyczących między innymi poziomu zatrudnienia, udziału rolnictwa $w$ PKB, modernizacji i poprawy produktywności, podjęła próbę oceny poziomu ich rozwoju. Według Poczty i in. (2015) czynniki determinujące potencjał rozwojowy rolnictwa rodzinnego w UE to przede wszystkim: wielkość gospodarstwa, zasoby pracy własnej oraz wartość produkcji.

Celem tego opracowania jest wskazanie głównych czynników, spośród analizowanych, determinujących rozwój rolnictwa w Unii. Do realizacji tego zadania wykorzystano analizę dyskryminacyjną.

\section{Materiał badawczy}

Empiryczną podstawę badań stanowiły dane GUS (Rocznik statystyczny rolnictwa 2017) i EUROSTATU (Agriculture 2016) na temat rolnictwa o 28 krajach UE w roku 2016. Dane te nawiązywały do wymienianych w literaturze czynników (tabela 1).

Zmienna $x_{26}$ jest destymulantą, pomnożenie jej wartości przez minus jeden spowodowało przekształcenie w stymulantę. Niektóre zmienne (np. udział pracujących w rolnictwie w ogólnej liczbie ludności (\%), czy wydatki na spożycie w gospodarstwach domowych na 1 mieszkańca (PPS /osobę) mają charakter nominat. Ich wartości w krajach UE nie powodują spadku poziomu badanego zjawiska (udział zatrudnionych w rolnictwie nie przekracza $5 \%$ za wyjątkiem Rumuni $-12,4 \%$, a wydatki na spożycie wiążą się bezpośrednio $\mathrm{z}$ popytem na artykuły rolno-żywnościowe, który stymuluje rozwój rolnictwa). 
Tabela 1. Zbiór zmiennych diagnostycznych

Table 1. A collection of diagnostic variables

\begin{tabular}{|c|c|c|}
\hline Determinanty & Zmienne & Nazwa zmiennej \\
\hline \multirow{4}{*}{ Zasoby ziemi } & $\mathrm{x}_{1}$ & średnia powierzchnia gospodarstwa (ha) \\
\hline & $\mathrm{x}_{2}$ & powierzchnia gruntów ornych na 1 mieszkańca \\
\hline & $\mathrm{x}_{3}$ & udział gruntów ornych w powierzchni ogółem (\%) \\
\hline & $\mathrm{x}_{4}$ & udział gospodarstw > 50 ha w ogólnej liczbie gospodarstw rolnych (\%) \\
\hline \multirow{2}{*}{ Zasoby pracy } & $\mathrm{x}_{5}$ & udział pracujących w rolnictwie w ogólnej liczbie ludności (\%) \\
\hline & $\mathrm{x}_{6}$ & produktywność pracy (tys. EUR/AWU²) \\
\hline \multirow{5}{*}{ Struktura produkcji } & $\mathrm{x}_{7}$ & udział zasiewu zbóż w ogólnej powierzchni gruntów ornych (\%) \\
\hline & $\mathrm{x}_{8}$ & udział zasiewu ziemniaków w ogólnej powierzchni gruntów ornych (\%) \\
\hline & $\mathrm{X}_{9}$ & $\begin{array}{l}\text { udział zasiewu buraków cukrowych w ogólnej powierzchni gruntów } \\
\text { ornych (\%), }\end{array}$ \\
\hline & $\mathrm{x}_{10}$ & liczba bydła na 100 ha użytków rolnych \\
\hline & $\mathrm{x}_{11}$ & liczba trzody na 100 ha użytków rolnych \\
\hline \multirow{5}{*}{$\begin{array}{l}\text { Wydajność } \\
\text { produkcji }\end{array}$} & $\mathrm{x}_{12}$ & plony zbóż (dt/ha) \\
\hline & $\mathrm{x}_{13}$ & plony ziemniaków (dt/ha) \\
\hline & $\mathrm{x}_{14}$ & plony buraków cukrowych (dt/ha) \\
\hline & $\mathrm{x}_{15}$ & produkcja mięsa z uboju na 1 mieszkańca $(\mathrm{kg})$ \\
\hline & $\mathrm{x}_{16}$ & produkcja mleka na 1 mieszkańca $(\mathrm{kg})$ \\
\hline \multirow{3}{*}{ Środki produkcji } & $\mathrm{x}_{17}$ & powierzchnia gruntów ornych na 1 traktor (ha) \\
\hline & $\mathrm{x}_{18}$ & zużycie środków ochrony roślin na 1 ha gruntów ornych $(\mathrm{kg})$ \\
\hline & $\mathrm{x}_{19}$ & zużycie nawozów mineralnych i chemicznych na 1 ha gruntów ornych $(\mathrm{kg})$ \\
\hline \multirow{6}{*}{ Zasoby kapitałowe } & $\mathrm{x}_{20}$ & wartość produkcji roślinnej na 1ha użytków rolnych (EUR/ha) \\
\hline & $\mathrm{x}_{21}$ & wartość produkcji zwierzęcej na 1ha użytków rolnych (EUR/ha) \\
\hline & $\mathrm{x}_{22}$ & wartość przemysłu rolnego na 1ha użytków rolnych (EUR/ha) \\
\hline & $\mathrm{x}_{23}$ & udział rolnictwa w PKB (\%) \\
\hline & $\mathrm{x}_{24}$ & produktywność ziemi (EUR/ha użytków rolnych) \\
\hline & $\mathrm{x}_{25}$ & dochód rolniczy na jednostkę pracy (EUR/AWU) \\
\hline \multirow{3}{*}{$\begin{array}{l}\text { Popyt na artykuły } \\
\text { żywnościowe }\end{array}$} & $\mathrm{x}_{26}$ & wydatki na spożycie w sektorze wydatków gospodarstw domowych (\%) \\
\hline & $\mathrm{x}_{27}$ & $\begin{array}{l}\text { wydatki na spożycie w gospodarstwach domowych na } 1 \text { mieszkańca } \\
\text { (PPS } 3 / \text { osobę) }\end{array}$ \\
\hline & $\mathrm{X}_{28}$ & $\begin{array}{l}\text { eksport produktów rolno-żywnościowych na } 1 \text { ha użytków rolnych } \\
\text { (EUR/ha) }\end{array}$ \\
\hline
\end{tabular}

Źródło: opracowanie własne.

\footnotetext{
${ }^{2}$ AWU (Annual Work Unit) to jednostka służąca do pomiaru nakładów pracy w rolnictwie, ekwiwalent pełnego etatu pracy własnej i najemnej ( $1 \mathrm{AWU}=2120$ godzin pracy $\mathrm{w}$ roku).

${ }^{3}$ PPS (Purchasing Power Standards) - miara siły nabywczej w krajach funkcjonujących w różnych systemach walutowych.
} 
Do określenia produktywności ziemi i pracy przyjęto jako miernik relację wartości dodanej brutto rolnictwa w cenach producentów do odpowiednio: powierzchni użytków rolnych lub jednostek AWU (Piwowar 2017).

\section{Metoda badawcza}

Główną metodą badawczą jest analiza dyskryminacyjna, która wymaga wstępnego podziału obiektów (krajów członkowskich UE). Za pomocą metody k-średnich (Sobolewski, Sokołowski, 2017), na podstawie wszystkich zmiennych diagnostycznych, podzielono wstępnie kraje unijne na 4 grupy. Istnieje wiele sposobów wyznaczania liczby grup (Gatnar, Walesiak). W tym opracowaniu liczbe grup $(k)$ ustalono symulacyjnie obliczając wariancje wewnątrzgrupowe $\left(S_{w}^{2}\right)$ oraz iloraz wariancji wewnątrzgrupowej i międzygrupowej $\left(S_{w}^{2} / S_{m}^{2}\right)($ Gatnar, 2011) dla $k=2, \ldots, 5$ (dalsze zwiększanie liczby grup powoduje powstawanie podzbiorów pustych lub o małej liczebności). Najmniejsze wartości obliczonych wariancji zadecydowały o podziale państw na 4 grupy.

Z założeń analizy dyskryminacyjnej (McLachlan, 1992) wynika, że dane (ujęte w postaci zmiennych diagnostycznych) winny reprezentować próbę z wielowymiarowego rozkładu normalnego. Test Kołmogorowa-Smirnowa (Krzyśko, 2004) wykluczył 7 zmiennych $\left(\mathrm{x}_{8}, \mathrm{x}_{11}, \mathrm{x}_{20}, \mathrm{x}_{21}, \mathrm{x}_{22}, \mathrm{x}_{24}, \mathrm{x}_{28}\right) \mathrm{z}$ dalszych badań, gdyż ich prawdopodobieństwo testowe o zgodności rozkładu normalnego było mniejsze od poziomu istotności 0,05 .

Ponadto program Statistica sprawdza dla każdej zmiennej tak zwaną wartość tolerancji, która pozwala uniknąc błędów związanych z niespełnieniem innych założeń analizy dyskryminacyjnej (Radkiewicz, 2010).

Wartości zmiennych poddano standaryzacji (Zeliaś, 2000), aby uniezależnić wyniki analiz od jednostek pomiaru poszczególnych zmiennych za pomocą wzoru:

$$
z_{i j}=\frac{x_{i j}-\bar{x}_{j}}{s_{j}}
$$

gdzie: $x_{i j}$ - wartość $j$-tej zmiennej dla $i$-tego kraju,

$\bar{x}_{j}-$ wartość średnia danej zmiennej,

$s_{j}$ - odchylenie standardowe.

Tabela 2. Zmienne o wysokiej mocy dyskryminacyjnej

Table 2. Variables with high discriminative power

\begin{tabular}{c|rrrrc}
\hline Zmienne & $\begin{array}{c}\text { Lambda } \\
\text { Wilksa }\end{array}$ & $\mathrm{F}$ & $p$ & Tolerancja & $\begin{array}{c}\text { 1-Tolerancja } \\
\text { (R kwadrat) }\end{array}$ \\
\hline $\mathrm{x}_{6}$ & 0,0217 & 4,7609 & 0,0191 & 0,2934 & 0,7066 \\
$\mathrm{x}_{7}$ & 0,0554 & 17,9502 & 0,0000 & 0,5834 & 0,4166 \\
$\mathrm{x}_{25}$ & 0,0487 & 14,9546 & 0,0000 & 0,2412 & 0,7588 \\
$\mathrm{x}_{27}$ & 0,0367 & 9,3596 & 0,0003 & 0,6626 & 0,3374 \\
\hline
\end{tabular}

Źródło: obliczenia własne wykonane za pomocą pakietu Statistica. 
W analizie dyskryminacyjnej do klasyfikacji obiektów wykorzystuje się tylko zmienne o wysokiej mocy dyskryminacyjnej. Do ich wyboru wykorzystano testy: Lambda Wilksa i F (Khattre i Naik, 2000), które znacznie ograniczyły listę zmiennych do dalszych badań (tabela 2)

Im mniejsza wartość statystyki Lambda Wilksa i im większa wartość statystyki F, tym większa moc dyskryminacyjna zmiennych. Krytyczny poziom $p$ bliski 0 weryfikuje hipotezę, że wszystkie zmienne są istotne w modelu wyjaśniającym zróżnicowanie grup krajów unijnych. Na podstawie zmiennych o wysokiej mocy dyskryminacyjnej oszacowano funkcje: dyskryminacyjne i klasyfikacyjne. Funkcję dyskryminacyjną według Stanisza (2007) opisuje wzór:

$$
D_{\mathrm{i} g}=e_{0}+e_{1} x_{1_{i g}}+e_{2} x_{2_{i g}}+\cdots+e_{p} x_{p i g}
$$

gdzie:

$D_{i g}$ - wartość kanonicznej funkcji dyskryminacyjnej dla $i$-tego przypadku w $g$-tej grupie, $i=1,2, \ldots, n$ oraz $g=1,2, \ldots, k$,

$e_{j}$ - współczynniki kanonicznej funkcji dyskryminacyjnej wyznaczone na podstawie własności tej funkcji, dla $j=1,2, \ldots, p$,

$p$ - liczba zmiennych dyskryminacyjnych,

$x_{j i g}$ - wartości $j$-tej zmiennej diagnostycznej dla $i$-tego przypadku w $g$-tej grupie.

Maksymalna liczba oszacowanych funkcji jest równa liczbie zmiennych o wysokiej mocy dyskryminacyjnej lub liczbie grup minus jeden (w zależności, która $\mathrm{z}$ nich jest mniejsza) (Radkiewicz 2010). Spośród nich należy wybrać funkcję o najwyższej wartości własnej i najwyższym procentowym jej udziale w ogólnej wariancji międzygrupowej. Funkcja ta pozwoli utworzyć grupy o podobnym poziomie rozwoju i uszeregować je.

Natomiast liczba funkcji klasyfikacyjnych o ogólnej postaci

$$
K_{g}=\mathrm{c}_{\mathrm{g} 0}+\mathrm{c}_{\mathrm{g} 1} \mathrm{x}_{1}+\mathrm{c}_{\mathrm{g} 2} \mathrm{x}_{2}+\cdots+\mathrm{c}_{\mathrm{gj}} \mathrm{x}_{\mathrm{j}} \quad g=1,2, \ldots, k
$$

gdzie:

$\mathrm{K}_{\mathrm{r}}-$ g-ta funkcja klasyfikacyjna,

$\mathrm{c}_{\mathrm{r} 0}$ - stała dla $g$-tej grupy

$\mathrm{c}_{\mathrm{rj}}$ - współczynniki przy $j$-tej zmiennej dyskryminacyjnej dla $g$-tej funkcji

$\mathrm{x}_{\mathrm{j}}$ - wartości standaryzowana dla $j$-tej zmiennej dyskryminacyjnej,

jest równa liczbie grup. Dany kraj należy przyporządkować do grupy, dla której będzie miał największą wartość klasyfikacyjną.

\section{Wyniki badań}

Z badań wynika, że głównie zmienne dotyczące: zasobów pracy (przedstawionych jako produktywności pracy), struktury zasiewów, których przykładem jest udział zasiewu zbóż w ogólnej powierzchni gruntów ornych, zasobów kapitału (wyrażonych za pomocą dochodu rolniczego na jednostkę pracy) oraz popytu na artykuły żywnościowe (reprezentowanego przez wydatki na spożycie w gospodarstwach domowych na 1 mieszkańca) determinują rozwój rolnictwa w UE. Oszacowana na ich podstawie funkcja dyskryminacyjna 


$$
F=-0,564 x_{6}+0,649 x_{7}+1,707 x_{25}+0,795 x_{27}
$$

ma najwyższą wartość własną $(15,549)$ oraz wyjaśnia 85,96\% wariancji międzygrupowej. Największy wpływ na kształtowanie wartości tej funkcji mają zmienne dotyczące dochodów rolniczych $\left(\mathrm{x}_{25}\right)$ i wydatków na spożycie $\left(\mathrm{x}_{27}\right)$. Na podstawie tej funkcji wyznaczono wartości kanoniczne (wartości funkcji dyskryminacyjnej) dla każdego kraju i przeciętne dla każdej grupy. Wartości kanoniczne grup (tabela 3) wskazują na ich zróżnicowanie i poziom rozwoju.

Tabela 3. Przeciętne wartości funkcji dyskryminacyjnej dla grup

Table 3. Average values of the discriminant function for groups

\begin{tabular}{c|c}
\hline Grupy & $\begin{array}{c}\text { Średnie wartości } \\
\text { kanoniczne }\end{array}$ \\
\hline I & 5,285 \\
II & 1,171 \\
III & $-2,998$ \\
IV & $-3,737$
\end{tabular}

Źródło: obliczenia własne wykonane za pomocą pakietu Statistica.

Najwyższy poziom rozwoju rolnictwa pod względem badanych cech występuje w grupie I, która znacznie odgranicza się od pozostałych grup. Wraz ze spadkiem średnich wartości kanonicznych poziom ten pogarsza się. Dwie ostatnie grupy charakteryzują się zbliżonym poziomem rozwoju rolnictwa.

Natomiast funkcje klasyfikacyjne analizy dyskryminacyjnej przyporządkowują dany kraj do jednej z wcześniej utworzonych grup. Tabela 5 zawiera wyniki oszacowań tych funkcji.

Tabela 4. Współczynniki funkcji klasyfikacyjnych

Table 4. Coefficients of classification functions

\begin{tabular}{c|rrrr}
\hline \multirow{2}{*}{ Zmienne } & \multicolumn{4}{|c}{ Grupy } \\
& \multicolumn{1}{|c}{ I } & \multicolumn{1}{c}{ II } & \multicolumn{1}{c}{ III } & \multicolumn{1}{c}{ IV } \\
\hline stała & $-169,002$ & $-104,679$ & $-52,572$ & $-53,784$ \\
$\mathrm{X}_{6}$ & $-1,205$ & $-1,172$ & $-1,038$ & $-0,545$ \\
$\mathrm{X}_{7}$ & 1,487 & 1,130 & 0,597 & 1,021 \\
$\mathrm{X}_{25}$ & 0,007 & 0,006 & 0,004 & 0,003 \\
$\mathrm{X}_{27}$ & 0,005 & 0,004 & 0,004 & 0,003 \\
\hline
\end{tabular}

Źródło: obliczenia własne wykonane za pomocą pakietu Statistica.

Dla każdego kraju obliczono wartości wszystkich funkcji klasyfikacyjnych. Dany kraj przyporządkowano do grupy, dla której miał on największą wartość klasyfikacyjną. Największy wpływ na przydział krajów do poszczególnych grup miały zmienne: udział zasiewu zbóż w ogólnej powierzchni gruntów ornych $\left(\mathrm{x}_{7}\right)$ i produktywność pracy $\left(\mathrm{x}_{6}\right)$. Wskazują na to najwyższe, bezwzględne wartości współczynników stających przy tych zmiennych. Wyniki klasyfikacji przedstawia tabela 5. 
Tabela 5. Klasyfikacja krajów UE do poszczególnych grup

Table 5. A classification of EU countries to particular groups

\begin{tabular}{|c|c|c|}
\hline Grupa & Liczebność & Kraje \\
\hline I & 8 & Belgia, Dania, Francja, Hiszpania, Holandia, Niemcy, Wielka Brytania \\
\hline II & 7 & Austria, Czechy, Finlandia, Irlandia, Luksemburg, Słowacja, Szwecja, Włochy \\
\hline III & 3 & Cypr, Malta, Portugalia \\
\hline IV & 10 & $\begin{array}{l}\text { Bułgaria, Chorwacja, Estonia, Grecja, Litwa, Łotwa, Polska, Rumunia, Słowenia, } \\
\text { Węgry }\end{array}$ \\
\hline
\end{tabular}

Źródło: opracowanie własne za pomocą programu Statistica.

Charakterystykę głównych czynników determinujących poziom rozwoju rolnictwa w poszczególnych grupach, skupiających kraje UE, umożliwiają wykresy1-4. Wskazują one wahania wielkości poszczególnych zmiennych oraz ich wartości średnie.

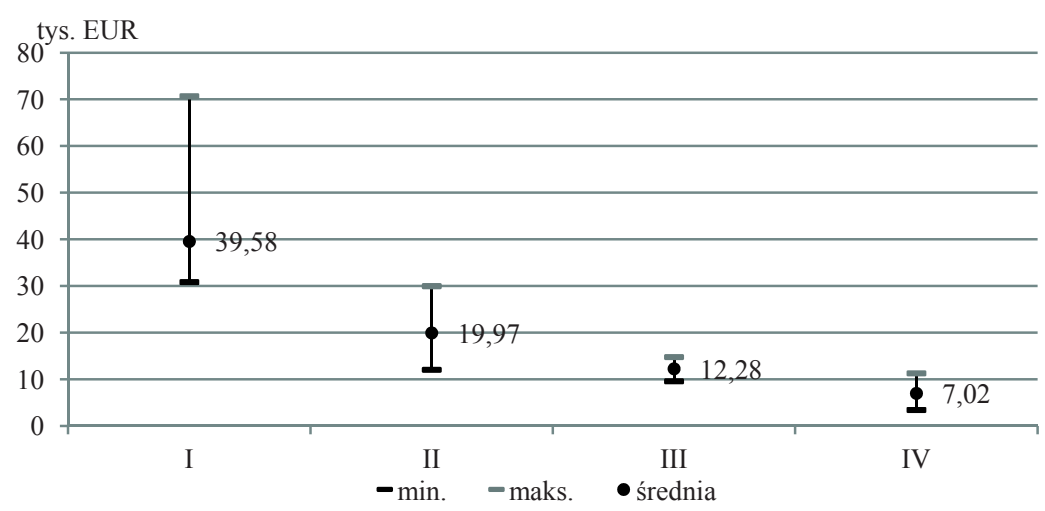

Rys. 1. Produktywność pracy na jednostkę AWU

Fig. 1. A labor productivity per AWU unit

Źródło: opracowanie własne.

W krajach należących do I grupy jednostkowa produktywność pracy jest najwyższa. Mieści się ona $\mathrm{w}$ przedziale: 30853 EUR/AWU (w Hiszpanii) - 70685 EUR/AWU (w Holandii). W kolejnych grupach średnia produktywność pracy jest coraz mniejsza. Najniższa produktywność pracy występuje w Łotwie (3465 EUR/AWU). 


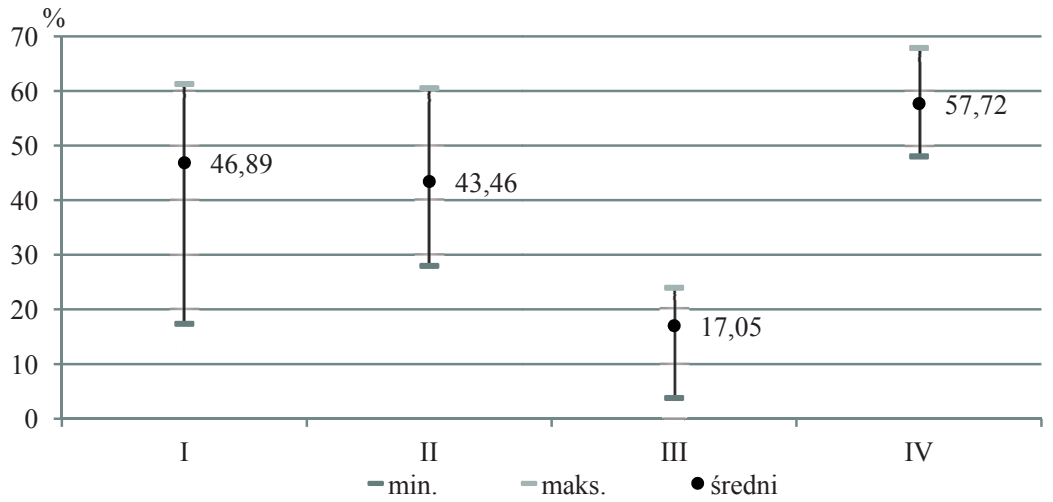

Rys. 2. Udział zbóż w ogólnej powierzchni gruntów ornych

Fig. 2. A share of cereals in the total area of arable land

Źródło: opracowanie własne.

Średni udział zbóż w ogólnej powierzchni gruntów ornych w grupie I i II w roku 2016 był zbliżony. Najmniej zbóż było uprawiane w grupie III a dokładnie na Malcie (zboża zajmowały tylko $3,8 \%$ powierzchni zasiewów). W grupie IV zboża stanowiły od 48,05\% (w Grecji) do 67,89\% (w Polsce) powierzchni gruntów ornych.

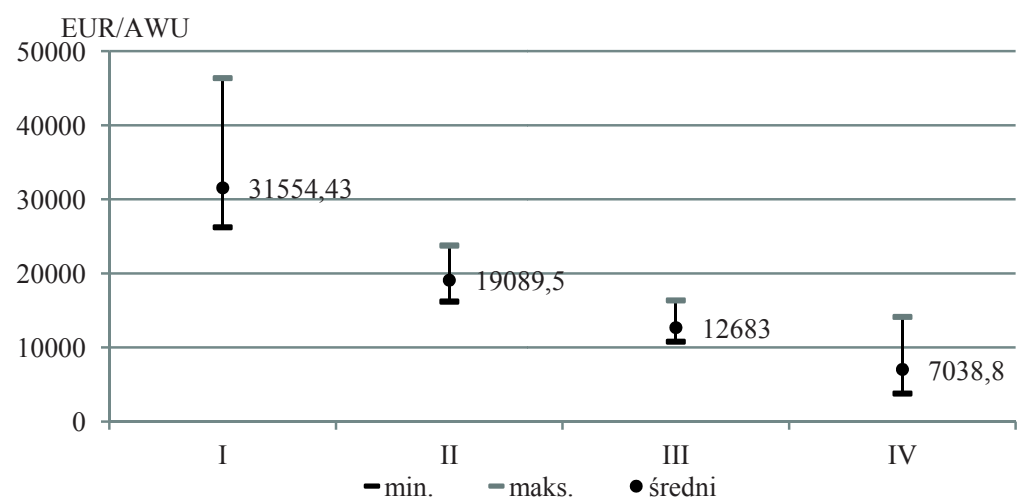

Rys. 3. Jednostkowe dochody rolnicze

Fig. 3. Individual agricultural incomes

Źródło: opracowanie własne.

Jednostkowe dochody rolnicze potwierdzaja prawidłowe uszeregowanie grup, skupiających kraje UE, pod względem poziomu rozwoju rolnictwa. Średni dochód w grupie I był prawie 4,5-krotnie wyższy niż w grupie IV. Najwyższy jednostkowy dochód uzyskano w Holandii (46360EUR/AWU) a najniższy w Rumunii (3786EUR/AWU). 


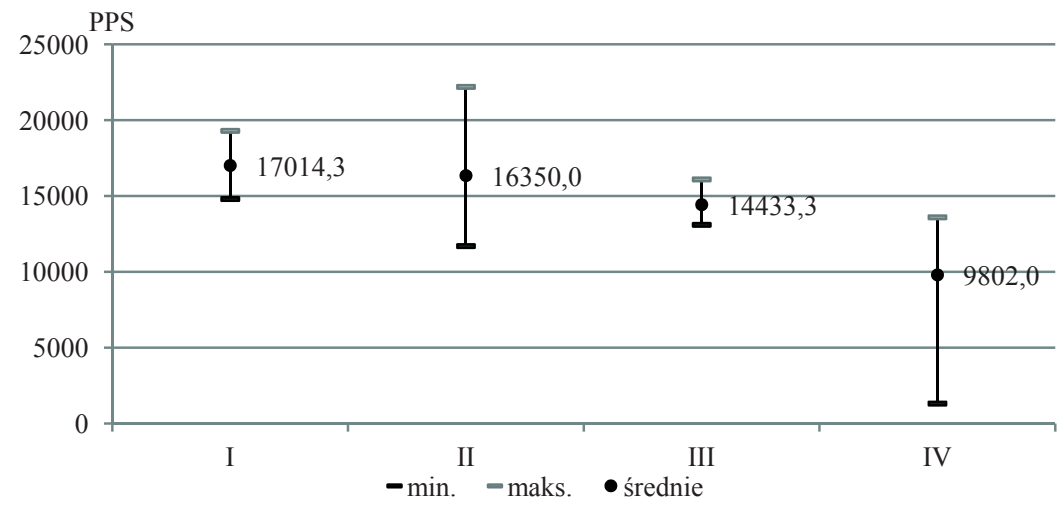

Rys. 4. Wydatki na spożycie w gospodarstwach domowych na 1 mieszkańca

Fig. 4. Consumption expenditures in households per capita

Źródło: opracowanie własne.

Wraz ze wzrostem numeru grupy maleją średnie wydatki na spożycie w gospodarstwach domowych na 1 mieszkańca. Najwyższe wydatki na spożycie odnotowano w Luksemburgu (22200 PPS na 1 mieszańca), ale stanowiły one tylko 27,8\% wszystkich wydatków w sektorze gospodarstw domowych. Najmniej na spożycie wydawali mieszkańcy krajów skupionych w grupie IV. Wydatki te wahały się od 1320 PPS na osobę w Grecji do 13600 PPS na osobę na Litwie.

\section{Podsumowanie}

Celem tego opracowania było wskazanie głównych czynników wpływających na rozwój rolnictwa w UE. Wskazane w literaturze przedmiotu (Przygodzka, 2006; Tomczak, 2006; Forgacs \& Beke, 2011; Beugelsdijk i in., 2017) determinanty rozwoju rolnictwa posłużyły do opracowania zbioru zmiennych diagnostycznych. Na ich podstawie wstępnie przydzielono kraje UE (metodą k-średnich) do czterech grup. Decydujące jednak znaczenie miały zmienne dotyczące: produktywności pracy, udziału zasiewu zbóż w ogólnej powierzchni gruntów ornych, dochodu rolniczego przeliczonego na jednostkę pracy oraz wydatków na spożycie w gospodarstwach domowych na 1 mieszkańca. Przeprowadzone w pracy badania pozwoliły wyodrębnić grupy, skupiające kraje o podobnym poziomem rozwoju rolnictwa oraz uszeregować je. Istnieją duże dysproporcje pod względem badanych cech pomiędzy krajami należącymi do różnych grup a leżącymi w podobnej strefie klimatycznej. Przykładowo udział zbóż w ogólnej powierzchni gruntów ornych w Polsce wynosi 67,89 a w Czechach 43,90\%. Wydatki na żywność w sektorze gospodarstw domowych we Włoszech (16800 PPS na 1 mieszkańca) były dwukrotnie wyższe niż w Bułgarii (8400 PPS na 1 mieszkańca). Produktywność pracy w Niemczech wynosiła 34444 EUR/AWU a w Polsce 4720 EUR/AWU. Dochód rolniczy w Austrii (16761 EUR/AWU) ponad czterokrotnie przewyższał dochód w Rumuni (3786 EUR/AWU).

Z kwerendy literaturowej wynika, że przydział krajów należących do pierwszej i ostatniej grupy jest zbliżony do podziału uzyskanego przez innych autorów (Bear- 
Nawrocka i Markiewicz, 2010; Janiszewska i Ossowska, 2014). Postęp technologiczny i biologiczny w krajach wysoko rozwiniętych (skupionych w I grupie) wpłyną na intensywność produkcji i zmniejszenie zależności rolnictwa od warunków przyrodniczych. Kraje IV grupy to głównie kraje postkomunistyczne o krótszym okresie przynależności do UE. Różnice w klasyfikacji wynikają z zastosowania innych metod badawczych, z wykorzystania innych zmiennych determinujących rozwój rolnictwa oraz z ustalenia innej liczby grup.

Kontynuacja takich badań w kolejnych latach pozwoliłaby stwierdzić: czy wydłużenie czasu przynależności do UE krajów grupy IV wpływa korzystnie na rozwój ich rolnictwa i czy zmniejszają się dysproporcje pomiędzy państwami przypisanymi do różnych grup pod względem badanych cech.

\section{Literatura}

Agriculture. (2016), Pobrane 17 maja 2018 z: http://ec.europa.eu/eurostat/web/agriculture/data/main-tables.

Baer-Nawrocka, A., Markiewicz, N. (2010). Zróżnicowanie przestrzenne potencjału produkcyjnego rolnictwa w krajach Unii Europejskiej (The spacial differentation of agricultural potential in eu countries). Roczniki Nauk Rolniczych, Seria G, 97(4), 9-15.

Beugelsdijk, S., Klasing, M., Milionis, P. (2017). Regional economic development in Europe: the role of total factor productivity. Regional Studies, 52(4), 461-476

McLachlan, G.J. (1992). Discriminant Analysis and Statistical Pattern Recognition. New York: John Wiley \& Sons Inc.,

Forgacs, A., Beke, J. (2011). Sustainability in the Agricultural sector of some EU countries. Journal of Economics and Business Research, 17(2), 64-79.

Gatnar, E. (2011). Podejście wielomodelowe w zagadnieniach dyskryminacji i regresji (A multi-model approach in issues of discrimination and regression). Warszawa: PWN.

Gatnar, E., Walesiak, M. (2004). Metody statystycznej analizy wielowymiarowej w badaniach marketingowych (Methods of multivariate statistical analysis in marketing research). Wrocław: Wydawnictwo Akademii Ekonomicznej.

Janiszewska, D., Ossowska, L. (2014). Zróżnicowanie rolnictwa krajów Unii Europejskiej na podstawie wybranych cech (Diversification of agriculture in the European Union on the basis of selected features), Problemy Rolnictwa Światowego, 14(1), 45-54.

Khattre, R., Naik, D.N. (2000). Multivariete data reduction and discrimination with SAS software. SAS Publishing INC.,New York: John Wiley\& Sons Inc.

Krzyśko, M. (2004). Statystyka matematyczna (Mathematical statistics). Poznań: Wydawnictwo Naukowe UAM.

Piwowar, A. (2017). Struktury rolne i produktywność rolnictwa w Grupie Wyszehradzkiej (Agricultural Structures and Productivity of Agriculture in the Visegrad Group). Problemy Rolnictwa Światowego, 17(1), 152-160.

Poczta, W., Szuba-Barańska, E., Beba, P., Czubak, W. (2015), Strukturalna i ekonomiczna różnorodność a możliwości rozwoju gospodarstw rodzinnych w UE (Family farms in the eu - their structural and economic diversity and opportunities of growth). Wieś i Rolnictwo, 1(166), 59-77.

Przygodzka, R. (2006). Fiskalne instrumenty wspierania rozwoju rolnictwa - przyczyny stosowania, mechanizmy i skutki, Białystok: Wydawnictwo Uniwersytetu w Białymstoku.

Radkiewicz, P. (2010). Analiza dyskryminacyjna. Podstawowe założenia i zastosowanie w badaniach społecznych (Discriminant analysis. Basic assumptions and applications in social research). Psychologia Społeczna, $5(2-3), 142-161$

Reardon, T., Barrett, Ch. (2000). Agroindustrialization, globalization, and international development: An overview of issues, patterns, and determinants. Agricultural Economics, 23(3), 195-205.

Rocznik Statystyczny Rolnictwa (Statistical yearbook of agriculture). (2017). 411-482. Pobrane 15 maja 2018 z: http://stat.gov.pl/obszary-tematyczne/roczniki-statystyczne/roczniki-statystyczne/rocznik-statystycznyrolnictwa-2017,6,11.html.

Sadowski, A., Poczta, W., Szuba-Barańska, E., Beba, P., Czubak, W. (2015). Model gospodarstwa rolnego w państwach Unii Europejskiej (Models of Farms in the European Union). Wieś i Rolnictwo, 3(168), 43-62.

Sobolewski, M., Sokołowski, A., (2017). Grupowanie metodą k-średnich z warunkiem spójności (Clustering Using K-Means Method with Coherence Property) Prace Naukowe UE we Wrocławiu, 468, 215-222. 
Stanisz, A. (2007). Przystępny kurs statystyki (Accessible statistics course). Tom 3, Kraków: Stat Soft Polska.

Szczukocka, A. (2015). Ocena poziomu rozwoju sektora rolnego w krajach Unii Europejskiej, (Assessment of the level of development of the agricultural sector in the European Union). Problemy Rolnictwa Światowego $15(1), 125-132$

Tomczak, F. (2006). Gospodarka rodzinna w rolnictwie: uwarunkowania i mechanizmy rozwoju (Family Agricultural Economy: Mechanism and Development Determinants), Warszawa: IRWiR, PAN.

Zeliaś, A. (2000). Metody statystyczne (Statistical methods). Warszawa: PWE.

Do cytowania / For citation:

Zaród J. (2018). Identyfikacja głównych determinant rozwoju rolnictwa w krajach Unii Europejskiej. Problemy Rolnictwa Światowego, 18(3), 342-352; DOI: 10.22630/PRS.2018.18.3.92

Zaród J. (2018). Identification of the Main Determinants of Agricultural Development in the European Union Countries (in Polish). Problems of World Agriculture, 18(3), 342-352;

DOI: 10.22630/PRS.2018.18.3.92 